\title{
Bilicsi Erika
}

\section{Hazai folyóiratok minősítése a Magyar Tudományos Müvek Tára alapján}

\author{
Ranking of Hungarian scientific journals based \\ on the Hungarian Scientific Bibliographic Database
}

\begin{abstract}
Absztrakt
A tudományos teljesítmény mérésének igénye számtalan kérdést vet fel. Sokféle mérési eljárás és mutató létezik, de egyik sem ad választ az olyan általános kérdésekre, hogy melyik folyóirat ,jobb" vagy melyik kutató teljesítménye színvonalasabb. Mindig meg kell fogalmazni, hogy mit, milyen okból kívánunk mérni, és ennek megfelelő mérési eljárást kell alkalmazni. Bármilyen mérési eljárást is választunk, adatbázisra, egy vizsgálandó halmazra van szükség ahhoz, hogy méréseket, összehasonlításokat lehessen végezni, rangsort lehessen elöállítani. Ennek az adatbázisnak pedig kellően nagy merítésűnek, az indexelt tartalom tekintetében teljesnek, az adatokra vonatkozóan pedig hitelesnek kell lennie, hiszen, ha túl kis halmazt elemezve vonunk le következtetéseket vagy csak részinformációk állnak rendelkezésre a vizsgálat tárgyairól, nem lesz pontos az eredmény, és egyesek hátrányba, mások megalapozatlanul előnybe kerülnek. A magyar kutatások eredményeinek minősítésére kiváló eszköz a Magyar Tudományos Müvek Tára (MTMT). Ennek a rendszernek az adatait használva készített folyóirat-rangsort Sasvári Péter, a Nemzeti Közszolgálati Egyetem kutatója. A kéziratot 2020. december 31-én Az MTA IX. Gazdaság- és Jogtudományok Osztály hazai folyóiratainak hivatkozásalapú helyezése 2021-ben címmel tette közzé a ResearchGate-en. Nagyon örülünk a kezdeményezésnek és reméljük, hogy a jövőben egyre szélesebb körben fogják használni az MTMT-t a kutatásértékelésben. Most mégis az MTMT helytelen használatának veszélyeire hívjuk fel a figyelmet, példaként használva a közreadott kéziratot. Az MTMT a jelenlegi müködési modell szerint közösségi termék és mint ilyen, meglehetősen vegyes minőségü rekordokat tartalmaz, ezért kellő körültekintéssel kell használni az értékelésben. Ha megszervezzük köré a bekerülő adatok teljességét biztosító
\end{abstract}


és hitelesítéséhez szükséges munkafolyamatokat, ha erőforrást rendelünk a folyamatos adattisztításhoz, ha gondoskodunk arról, hogy csak a validált adatokon alapuljanak a minősítésekhez használt statisztikák, akkor meglátjuk, hogy kiváló eszköz van a kezünkben, amit nagyon sok módon és területen lehet hasznosítani.

Kulcsszavak: tudományos publikálás, folyóirat, minősítés, rangsor, Magyar Tudományos Mủvek Tára (MTMT)

\begin{abstract}
The need to measure the efficiency of scientific research raises a myriad of questions. There are many different measurement methods and indicators, but none give answers to the general questions like which journal is "better" or which researcher is more effective. It is always necessary to state what we want to measure, for what reason and choose the corresponding measurement process. Whatever measurement method we choose, we need a database to perform measurements and comparisons and generate rankings. This database must be complete in terms of indexed content and validated in terms of metadata because if we draw conclusions by analyzing a too small set or not correct information, the result will not be accurate and some will be disadvantaged, others unduly favored. The Hungarian Scientific Bibliographic Database (MTMT) is an excellent tool for evaluating the results of Hungarian research. Péter Sasvári, a researcher at the National University of Public Service, created a journal ranking of Hungarian journals that are on the accepted journals' list of the Hungarian Academy of Sciences IX. Section of Economics and Law using the data of this system. The manuscript was published on 31 December 2020 on ResearchGate. We are very pleased with the initiative and hope that MTMT will be increasingly used in research evaluation in the future. However, we illustrate the dangers of incorrect use of MTMT, using the published manuscript as an example. The cause of this is that MTMT is a community product according to the current operating model, therefore it has rather mixed quality records. It should be used with due care in the evaluation. If we organize the workflows around it to ensure the completeness and validation of the incoming records, if we take care of continuous data correction and if we make sure that the statistics used for ratings are based only on validated records, we will see that we have an excellent tool in our hands that can be utilized in many ways and areas.
\end{abstract}

Keywords: scientific publication, journal, certification, ranking, Hungarian Scientific Bibliographic Database 


\section{A tudományos teljesítmény mérésének kihívásai}

A tudományos teljesítmény értékelése számtalan kérdést vet fel. Általában a kutatások eredményeként megjelenő publikációkat értékelve szokás rangsorokat felállítani, de nehéz figyelembe venni minden változót: foglalkozni kell a szakterületek közötti különbségekkel, a dokumentumtípusok jellemzőivel. ${ }^{1}$ Ebböl kifolyólag számos mutató létezik és mindig újabbak jelennek meg, melyek célja, hogy árnyaltabb, pontosabb képet adjanak. A Magyar Tudományos Müvek Tára (MTMT) adminisztrátorként azt tapasztaljuk, hogy a minősítést használóknak egy olyan mutatóra lenne igénye, ami minden helyzetben, minden körülmények között kifejezi, hogy melyik kutató teljesítménye színvonalasabb, melyik folyóirat „jobb”, melyik tanulmány kiemelkedő. Nyilvánvalóan nem létezik olyan eljárás - sem most, sem a jövőben -, ami ezt az igényt ki tudná szolgálni. Tehát az értékelöknek és az értékelést előállítóknak együtt kell müködniük: meg kell fogalmazni, hogy mit, milyen okból kívánunk mérni, ezután ennek megfelelő mérési eljárást kell kidolgozni, végül pedig mindig az adott helyzetnek és igényeknek megfelelően kiválasztva a mutatót, alkalmazni azt. Ám bármilyen kiváló új mutatót alkotunk is, soha nem fog létezni olyan, ami a szakmai tartalom alapján minősítene. A humán értékelés soha nem lesz kivonható a minősítési eljárásokból, de a mennyiségeken alapuló mutatók egyfajta előszürést biztosíthatnak. Ezáltal megkönnyítik a kutatók munkáját akkor is, amikor színvonalas szakirodalmat keresnek kutatásaikhoz vagy, amikor a legjobb helyet keresik a publikálásra, esetleg támogatások elosztásáról van szó és akkor is, amikor a szakma legjobbjainak a kiválasztása a cél. Bármilyen mérési eljárást is választunk, adatbázisra, egy vizsgálandó halmazra van szükség ahhoz, hogy méréseket, összehasonlításokat lehessen végezni, rangsort, statisztikát lehessen elóállítani. Ennek az adatbázisnak pedig kellően nagy merítésűnek, az indexelt tartalom tekintetében teljesnek, az adatokra vonatkozóan pedig hitelesnek kell lennie, hiszen, ha túl kis halmazt elemezve vonunk le következtetéseket vagy csak részinformációk állnak rendelkezésre a vizsgálat tárgyairól, nem lesz pontos az eredmény és egyesek hátrányba, mások megalapozatlanul előnybe kerülnek. A nemzetközi publikálást vizsgáló tudományelemzéssel foglalkozó szakemberek leggyakrabban a Web of Science, illetve a Scopus adatbázisok tartalmára támaszkodnak. Ezek a piacvezető adatbázisok sem tartalmaznak ,mindent”, megválogatják, hogy mik azok a kiadványok, amiknek az adatait gyüjtik, azaz amiket indexelnek (de a válogatott kiadványok tartalmát maradéktalanul feldolgozzák, tehát ebből a szempontból az adatbázisok

1 A Declaration on Research Assessment (DORA) nemzetközi kezdeményezés is azért született 2012ben, hogy javuljanak a tudományos értékelésben használt módszerek (URL2). 
teljesek). Ennek részben az az oka, hogy megfelelő technikára van szükség ahhoz, hogy a kiadványok adatai megjelenés után mindig, hiánytalanul és pontosan bekerüljenek az adatbázisba. Ha például egy folyóirat nem rendszeresen jelenik meg vagy nem alakítható ki automatizált eljárás az adatok begyüjtésére, akkor ma már lehet az bármilyen színvonalas kiadvány, nem tud bejutni az ilyen bibliográfiai adatbázisok gyüjteményébe. Így kívánják garantálni a kereskedelmi szolgáltatók, hogy az általuk értékesített termék adatain alapuló mutatók helyesek legyenek. Tehát ezek sem univerzálisan használható mutatókat szolgáltatnak, mindig hozzá kell tenni az ezekre alapozott elemzésekhez is, hogy melyik adatbázis alapján született az eredmény.

Sajnos természetesen a nyelv is korlátozó tényezö. Ha a nemzetközi bibliográfiai adatbázisokba való bekerülésről van szó, nyilvánvalóan előnyben vannak az angolul, illetve világnyelveken megjelenő kiadványok, hiszen, ha az adatbázist üzemeltető személyzet nem ismeri az adott nyelvet, igen nehezen fogja elvégezni az adatok feldolgozását és nagy valószínüséggel hibásan is. Ne feledkezzünk meg arról sem, hogy nem attól lesz tudományos, színvonalas egy folyóirat, ha szerepel mondjuk a Web of Science-ben, illetve a Scopusban vagy ha DOI-ja van. Ezek technikai eszközök, melyek megkönnyítik az értékeléseket előállítók munkáját (bár ilyen eszközök nélkül - tekintettel a hatalmas publikálási dömpingre - ma már nem is lehetne effajta munkát végezni), de a szakmai tartalom az, ami tudományossá, színvonalassá tesz egy folyóiratot: azaz egy magyarországi vidéki múzeum évkönyvében megjelent tanulmány lehet ugyanolyan kiemelkedő, mint egy nemzetközi orvosi folyóiratban publikált cikk. Persze sosem fog rendelkezni ugyanolyan, manapság jónak ítélt mutatókkal, hiszen például egy rákkutatási téma világszerte nagy érdeklődésre tart számot, sokan foglalkoznak vele, sokan idézhetik, míg egy magyar nyelven publikált tanulmány mondjuk a Kis-Sárréten feltárt halmokról, nem számíthat ugyanerre.

\section{A Magyar Tudományos Múvek Tára}

A hazai kiadványok minősítésére tehát meg kell találnunk a saját eljárásainkat, melyek biztosítják, hogy a kutatók ki tudják választani, melyek azok a kiadványok, amiket érdemes olvasni és amikben érdemes publikálni. A szerkesztőségi munka biztosítja, hogy csak megalapozott eredményeket tartalmazó tanulmányok jelenhessenek meg és a cikkek metaadatai bekerüljenek olyan adatbázisokba, amik azt biztosítják, hogy az olvasók megtalálják, olvashassák a múveket, és a kutatásértékelésben is rangos eredményeket produkáljon a kiadvány, ezáltal hozzásegítve a kutatókat pályázati források elnyeréséhez. 
Szerencsések vagyunk, hiszen rendelkezésünkre áll az MTMT. Más országokban nem feltétlenül létezik effajta bibliográfiai adatbázis, ami a kiadványokat analitikusan - azaz tanulmányonként - dolgozza fel. A könyvtárak katalógusai egyben az intézmény leltárát is biztosítják, így a legtöbb esetben a szükös erőforrások miatt példányszintü a feldolgozás. Arról nem is beszélve, hogy a könyvtárak adatbázisai olyan mértékü feltárást nem tartalmaznak, melyek rögzítenék egy tanulmányról, hogy például az szakcikk vagy könyvismertetés. Hazánkban több kezdeményezés is történt folyóiratok cikkszintü kereshetőségének biztosítására, ilyen például a MATARKA, az EPA vagy a HUMANUS. De az MTMT nemcsak a folyóiratcikkek adatait gyüjti: a könyvek, könyvfejezetek, konferenciakiadványban megjelent tanulmányok, sőt még a kutatási adatok indexelésére is felkészült. Ráadásul az 1994. évi XL. törvény a Magyar Tudományos Akadémiáról ${ }^{2}$ tartalmazza, hogy „6. § (1) o) az e tevékenységet alapfeladatként ellátó, az MTA Könyvtár és Információs Központ mint akadémiai költségvetési szerv (a továbbiakban: Könyvtár és Információs Központ) közremüködésével tudományos müvek (tudományos alkotás, tudományos publikáció, doktori értekezés és annak tézisei, MTA doktora értekezés és annak tézisei) adatait tartalmazó nemzeti tudományos bibliográfiai adatbázist (a továbbiakban e törvény alkalmazásában: Adatbázis) müködtet, amely bibliográfiai hitelesség szempontjából ellenörzött módon tartalmazza a költségvetési szerveknél foglalkoztatottak által a szerzői jogról szóló 1999. évi LXXVI. törvény 30. § (7) bekezdésében meghatározott jogviszonyuk keretei között megalkotott és nyilvánosságra hozott tudományos müvekkel, valamint a költségvetési forrásból tudományos mü megírására, létrehozására irányuló szerzödés alapján támogatásban részesülö személyek által megjelentetett tudományos müvekkel kapcsolatos, e törvény 19/A. §-ában meghatározott adatokat; valamint alkalmas a más személyek által megalkotott és nyilvánosságra hozott tudományos müvek önkéntesen közzétenni kívánt adatainak befogadására”. Tehát a jogalkotó jelenleg csak a költségvetési szerveknél kutatók által publikált tudományos müvek adatainak MTMT-be való feltöltését tette kötelezővé, hiszen a tudományos kutatások nyilvántartására és értékelésére alkalmas adatbázis müködtetése a jelenlegi cél. Azonban, ha kötelezővé tenné a Magyarországon megjelentetett kiadványok adatainak feltöltését - hasonlóan A kiadványok kötelespéldányainak szolgáltatásáról, megőrzéséről és használatáról szóló 195/2019. (VIII. 1.) Korm. rendelethez, ami elöírja, hogy a Magyarországon megjelentetett kiadványokból küldeni kell az Országos Széchényi Könyvtár számára -, máris

2 Kiegészítette a 2015. évi CXXXI. törvény egyes, a felsőoktatás szabályozására vonatkozó törvények módosításáról (URL3). 
rendelkezésre állna egy olyan adatbázis, melyen nemcsak a kutatók publikálási tevékenységének értékelését, de a hazai folyóiratok vagy akár kiadók munkájának elemzését is el lehetne végezni.

Számos hasonló esetben hasznos lehet az MTMT: például, ha egy kutatástámogató elöírja, hogy a támogatott kutatás eredményeként született publikációk adatait fel kell tölteni az MTMT-be, és a rekordban fel kell tüntetni a támogatás azonosítóját, akkor az egyes projektekhez kapcsolódó publikálási tevékenységről is adatokat lehetne kinyerni az MTMT-böl.

Hangsúlyozzuk, mindig az elemzéshez szükséges halmaz előállításáról és hitelességének biztosításáról kell mindenekelőtt gondoskodni! Erre az MTMT technikailag felkészült (Holl, 2021, 81-89.), de a részt vevő intézményekben igen sokféle munkamenet müködik. Így az adatbázis jelenleg meglehetősen vegyes minőségü rekordokat tartalmaz, mivel az adatfeltöltés módja nem egységes, az ellenőrzés pedig nem teljeskörü. A publikációk adatait feltölthetik a szerzők, de vannak olyan intézmények, melyek MTMT adminisztrátorokat foglalkoztatnak, akik elvégzik ezt a kutatók helyett. Ez utóbbi esetben persze gondoskodni kell arról is, hogy a szerző tudassa az adminisztrátorral, ha megjelent egy közleménye (bárhol a világban). Más intézmények előírják a szerzők számára az adatok feltöltését, az adminisztrátorok pedig segítségükre vannak ebben, oktatásokat tartanak és ellenőrzik az adatfelvitel helyességét. Sajnos olyan szerzők is akadnak, akiknek nem áll rendelkezésére adminisztrátori segítség, számukra az MTA Könyvtár és Információs Központban dolgozó, jelenleg 13 fö központi adminisztrátora igyekszik segítséget nyújtani. A központi adminisztrátorok látják el az adatbázis üzemeltetésével kapcsolatos fejlesztési munkák kapcsán a szakmai felügyeletet, tesztelést, hibajavítások előkészítését, és helpdesket is biztosítanak a felhasználóknak. Az adatbázisba bekerülő rekordok tételes revíziója nem a központi adminisztráció feladata, csupán néhány eljáráshoz kapcsolódóan végeznek ellenőrzést, mint például az MTA doktora cím megszerzése. Természetesen ez a rekordok formai ellenőrzését jelenti, a legtöbb esetben a publikáció teljes szövege nem is áll az adminisztrátorok rendelkezésére. A rekordok hitelesítésére az intézményi adminisztráció szintjén van lehetőség, de sajnos ez jelenleg egy kevéssé kihasznált funkciója az adatbázisnak (Holl, 2021). Az álmunk az, hogy egy megfelelő létszámú csapat a Magyarországon megjelent kiadványok adatait analitikusan, hacsak lehet automatizáltan, de szükség esetén manuálisan feltöltse az MTMT-be, és létrejöjjenek a feltételei az adatbázis folyamatos revíziójának is, hogy hitelesített rekordok álljanak rendelkezésre az elemzésekhez. Ez drasztikusan csökkentené a szerzők és az intézményi adminisztrátorok adatfelviteli feladatait, de nyilvánvalóan nem lehet a közremüködésük nélkül múködtetni az MTMT-t. A külföldön megjelent 
magyar szakirodalom csak a segítségükkel kerülhet a bibliográfiába, és jelenleg nem olyan a publikálási kultúra sem, hogy a szerző személyét egyértelmüen azonosíthassa, a megfelelő intézményi affiliációt is beemelhesse a rekordba egy „idegen” adminisztrátor - bár egyedi azonosítók segítségével, mint például az ORCID és a GRID ez megoldható lenne.

A közlemények bekerülése után pedig a hivatkozások gyüjtése is gépesíthető lenne: ha a megjelentetett tanulmányok irodalomjegyzékében a felhasznált források DOI azonosítóit is feltüntetnék a szerzők, és ez a lista bekerülne az MTMT rekordba, akkor a DOI alapján még az idéző és az idézett rekordok is automatizáltan összeköthetők lennének az MTMT-ben. Természetesen ez esetben is meg kell hagyni a lehetőséget a kutatóknak arra, hogy olyan idézeteket is rögzíthessenek munkásságukhoz, melyek ilyen automatizált módszerrel nem felfedezhetők, de egy ilyen funkció tovább csökkentené az adatfelviteli terheket.

\section{Egy „hirtelen” összeállított rangsor pontatlanságai}

Az alábbiakban Sasvári Péter ResearchGate-en közzétett ,Az MTA IX. Gazdaság-és Jogtudományok Osztály hazai folyóiratainak hivatkozásalapú helyezése 2021-ben" címü kéziratának (Sasvári, 2020) elemzésével bemutatjuk, hogy mindez mennyire fontos, mennyire félrevezetö lehet, ha az MTMT adatait nem megfelelö körültekintéssel használják. Hangsúlyozzuk, hogy elemzésünk nem mindenre kiterjedő. Célunk az, hogy gondolatébresztő vizsgálatunk a rangsor publikálását követően hamar eljusson az esetleges felhasználókhoz, és hogy úgy végezzük az elemzést, hogy a lehető legkevesebb változás legyen az MTMT-ben a kutató és jelen elemzés elvégzésének ideje között (a rangsor publikálásának dátuma 2020. december 31., elemzésünket 2021. január 9-én végeztük).

Számos egyetemi könyvtár és az MTA Könyvtár és Információs Központ munkatársaihoz hasonlóan Sasvári Péter, a Nemzeti Közszolgálati Egyetem kutatója is évek óta foglalkozik - többek között - a hazai folyóiratok minősítésének kérdésével és a folyóirat-kiadás technikai kultúrájának emelésével. A munka eredményes, hiszen az utóbbi három évben gombamód jelentek meg hazánkban az OJS platformok, egyre körültekintőbbek a szerkesztőségek a honlapjukon közzétett információk tekintetében, sokan bevezették a DOI azonosító használatát, sőt egyre több szerkesztőség kezdte el feltölteni a megjelentetett cikkek adatait az MTMT-be és a cikkek PDF példányát archiválni repozitóriumban. 2020. december 31-én Sasvári úr közzétette a ResearchGate-en saját készítésú folyóiratrangsorát, mely az MTMT-ben elérhető adatokon alapszik. A lista az MTA IX. Gazdaság- és Jogtudományok Osztályának folyóiratlistáján (URL1) 
szereplő hazai folyóiratokat tartalmazza. Egyelöre a táblázathoz nem kapcsolódik publikáció - legjobb tudomásunk szerint -, ezért számos kérdésben csak találgatni tudunk, de már ezen a ponton felvetődhet, hogy mit tekintünk hazai lapnak. A IX. osztály listáján a célközönség oszlopban hazainak jelöltet, a magyar kiadónál megjelentet, a magyar nyelvüt, az MTMT-ben hazainak jelöltet stb. S mi a helyzet a határon túli magyar kiadású lapokkal?

A listán 212 rangsorolt folyóirat szerepel, valamint további 85 olyan folyóirat, ami minden bizonnyal azért nem került a rangsorba, mert annyira kevés volt az adat hozzájuk. A „Helyezés 2021” oszlop TOP 50 folyóiratát választottuk, hogy aggályainkat bemutassuk. Az MTMT eredeti koncepciójában a kiadói adatfelvitel nem szerepelt, így a rendszer nem minden nehézség nélkül kezeli jelenleg az effajta adatrögzítést. Hogy mely szerkesztőségek vállalták fel az adatfelvitelt, arról az MTMT nyilvános keresőjében az „Intézmények” között a „Kiadók” nevü intézményre keresve tájékozódhatunk. Jelenleg 245 szerkesztőségnek van hozzáférése az MTMT-hez, az ő munkájukat, azaz a kiadói adatfelvitelt az MTA KIK Szakinformatikai Osztályának munkatársai segítik, illetve ellenőrzik az adatfelvitel minőségét és szükség esetén javítanak.

A listán szereplö TOP 50 folyóirat közül csupán 19 rendelkezik adatfelviteli hozzáféréssel. A továbbiakban csak ezek további elemzésével foglalkozunk, hiszen a többi lap cikkei nagy valószínűséggel nem hiánytalanul szerepelnek az MTMT-ben (például a külföldi szerzők cikkei nyilvánvalóan hiányoznak), a szerkesztöségek csak azoknak az évfolyamoknak a hiánytalanságáért vállalhatnak felelősséget, melyeket maguk rögzítettek - a szerkesztőség csatolása különbözteti meg a kiadói adatfelvitelü rekordokat a szerzők, illetve az intézményi adminisztrátorok által feltöltöttektől.

Az, hogy egy kiadó adatfelviteli joggal rendelkezik, sajnos nem jelenti, hogy rendszeresen fel is tölti a cikkek adatait. A feltöltés mértéke néhány szerkesztőségnél kiváló, másoknál vannak elmaradások, akik pedig nem önkéntesen, hanem pályázati támogatás elnyerése miatt töltenek vagy töltöttek adatokat az MTMT-be, azokra jellemző, hogy évente egyszer, a pályázati elszámoláskor dolgoznak, illetve, ha nem kapnak további támogatást, nem folytatják az adatfelvitelt. Az alábbi táblázat azt mutatja, hogy az egyes szerkesztóségek mikor töltöttek be a legutóbbi alkalommal rekordot az MTMT-be és mi az első, illetve az utolsó füzetszám, ami kiadói adatfelvitellel, teljes egészében bekerült. 
1. számú táblázat: A szerkesztöségi adatfelvitel naprakészsége az MTMT-ben

\begin{tabular}{|c|c|c|c|}
\hline Folyóirat címe & $\begin{array}{c}\text { Első MTMT-ben } \\
\text { rögzített füzet }\end{array}$ & $\begin{array}{c}\text { Legutóbbi MTMT-ben } \\
\text { rögzített füzet }\end{array}$ & $\begin{array}{c}\text { Legutóbbi adatfelvitel } \\
\text { dátuma }\end{array}$ \\
\hline KOME & $2012 / 1$ & $2018 / 2$ & 2019. 04. 22. \\
\hline $\begin{array}{l}\text { Államtudományi } \\
\text { Mühelytanulmányok }\end{array}$ & & & még nem rögzített rekordot \\
\hline Közgazdasági Szemle & $2014 / 1$ & $2020 / 9$ & 2020.12 .08$. \\
\hline Történelmi Szemle & $2014 / 1$ & $2020 / 3$ & 2020.12 .14 . \\
\hline Pénzügyi Szemle & $2019 / 1$ & 2020/4 (és Special Issue) & 2020. 12. 22 . \\
\hline Tér és társadalom & $1987 / 1$ & $2020 / 4$ & 2020.11. 30 . \\
\hline $\begin{array}{l}\text { Észak-magyarországi Stratégiai } \\
\text { Füzetek }\end{array}$ & $2019 / 1$ & $2020 / 1$ & 2020.12 .16 \\
\hline Agrár- és Környezetjog ${ }^{3}$ & $2016 / 1$ & $2020 / 28$ & 2020.06 .27$. \\
\hline Magyar Rendészet & $2019 / 1$ & $2020 / 4$ & 2020.12 .03$. \\
\hline Századok & $2015 / 1$ & $2020 / 6$ & 2020.12 .15 \\
\hline Hadtudomány & $2014 / 1$ & $2020 / 3$ & 2020.12 .14$. \\
\hline Honvédségi Szemle & $2019 / 1$ & $2020 / 5$ & 2020.09. 30 . \\
\hline Belügyi Szemle & $2015 / 1$ & $2020 / 12$ & 2021.01 .05$. \\
\hline Pro Futuro & & & még nem rögzített rekordot \\
\hline Polgári Szemle & & & még nem rögzített rekordot \\
\hline $\begin{array}{l}\text { Academic and applied research in } \\
\text { military and public management } \\
\text { science }\end{array}$ & $2019 / 1$ & $2020 / 1$ & 2020.10 .30 \\
\hline In Medias Res & $2012 / 1$ & $2019 / 2$ & 2020.12.16. \\
\hline Információs társadalom & $2016 / 1$ & $2019 / 1$ & 2019.11 .27$. \\
\hline Szigma & $2014 / 1-2$ & $2020 / 1$ & 2020.07 .15 . \\
\hline
\end{tabular}

Forrás: A szerző saját szerkesztése az MTMT-ben

2021. január 9-én nyilvánosan elérhető adatok alapján.

A továbbiakban csak azoknak a lapoknak az elemzésével foglalkozunk, melyeknek a 2018. és 2019. évi cikkei rögzítésre kerültek az MTMT-ben, mivel a rangsor az ezekben az években megjelent cikkek MTMT-ben tárolt adatain alapul. A kiadói adatfelvitel csak a bibliográfiai adatokra terjed ki, azaz a kiadói adminisztrátorok csak akkor rögzítenek szerzői és/vagy intézményi hozzárendelést

3 A 2019. évi füzetek cikkeinek adatait nem töltötte fel a szerkesztőség az MTMT-be, azaz 2018-ban az adatfeltöltés megszakadt, 2020-ban újra elkezdték. 
a rekordokba, ha az a folyóiratban megjelent és teljes bizonyossággal megfeleltethető a megjelent adat az MTMT-ben szereplővel. Azaz a kiadók által rögzített rekordok számos esetben hiányosak, hiszen nem tartalmaznak szerzői, illetve intézményi hozzárendelést, így a nyilvános keresőfelületen nem jelennek meg. Az alábbi táblázat azt tartalmazza, hogy hány rekord látható az MTMT nyilvános keresőjében és a kiadók adminisztrátoraként az MTMT-be való belépés után keresve a szerkesztőségi intézményi hozzárendelést alapul véve.

2. számú táblázat: Az MTMT nyilvános keresőfelületén és az autentikációval elérhetö rekordok számának különbsége

\begin{tabular}{|c|c|c|c|c|c|c|}
\hline \multirow{3}{*}{$\begin{array}{l}\text { Folyóirat } \\
\text { címe }\end{array}$} & \multicolumn{6}{|c|}{ Közlemények száma } \\
\hline & \multicolumn{3}{|c|}{2018} & \multicolumn{3}{|c|}{2019} \\
\hline & $\begin{array}{c}\text { MTMT } \\
\text { nyilvános } \\
\text { keresőben } \\
\end{array}$ & $\begin{array}{l}\text { MTMT-ben } \\
\text { bejelentkezve }\end{array}$ & Rangsorban & $\begin{array}{l}\text { MTMT nyilvá- } \\
\text { nos keresőben }\end{array}$ & $\begin{array}{c}\text { MTMT-ben } \\
\text { bejelent- } \\
\text { kezve }\end{array}$ & Rangsorban \\
\hline $\begin{array}{l}\text { Közgazdasági } \\
\text { Szemle }\end{array}$ & 69 & 70 & 69 & 66 & 67 & 67 \\
\hline $\begin{array}{l}\text { Történelmi } \\
\text { Szemle }\end{array}$ & 37 & 40 & 38 & 36 & 37 & 36 \\
\hline $\begin{array}{l}\text { Tér és társada- } \\
\text { lom }\end{array}$ & 48 & 50 & 51 & 48 & 52 & 48 \\
\hline $\begin{array}{l}\text { Agrár- és Kör- } \\
\text { nyezetjog }\end{array}$ & 18 & 19 & 18 & 0 & 0 & 19 \\
\hline Századok & 78 & 83 & 80 & 78 & 88 & 78 \\
\hline Hadtudomány & 55 & 55 & 57 & 45 & 48 & 46 \\
\hline Belügyi Szemle & 74 & 96 & 75 & 59 & 73 & 59 \\
\hline In Medias Res & 18 & $\begin{array}{c}20 \\
(1 \text { munkapéldány })\end{array}$ & 19 & 16 & 18 & 16 \\
\hline Szigma & 5 & 5 & 8 & 12 & 15 & 13 \\
\hline
\end{tabular}

Forrás: A szerző saját szerkesztése az MTMT-ben 2021. január 9-én nyilvánosan elérhető adatok alapján.

Amennyiben a folyóiratok címére és a megjelenés évére kerestünk volna, még több rekord található az MTMT-ben, mert sajnos hiába a kiadói adatfelvitel, a szerzők és adminisztrátorok gyakorta megismétlik egy-egy cikk feltöltését. Az is előfordul, hogy ha egy adatfeltöltő nem találja a folyóiratok listájában a lapot amit keres, felveszi újként. Így ideiglenesen egy-egy folyóirat címe szerepelhet többször is az MTMT-ben, így kimaradhatnak cikkek, ha folyóirat cím szerint keresve próbáljuk meg lekérdezni egy adott év publikációit. Nem folytatjuk az esetleges hibák felsorolását, a hivatkozások lekérdezése kapcsán pedig el sem kezdjük. De arra még felhívjuk a figyelmet, hogy a hivatkozások feltöltéséhez a szerkesztőségeknek semmilyen jogköre nincsen, ezért ebből a szempontból teljes mértékben a véletlenen alapszik a publikált rangsor. 


\section{Összefoglalás}

A fenti példák minden bizonnyal kellö bizonytalanságot keltettek olvasóinkban. Bízunk benne, hogy nem keltik azt a benyomást, hogy az MTMT használhatatlan, hiszen ez nem igaz. Azonban figyelembe kell venni, hogy az MTMT az adatfelvitel elvét tekintve igencsak hasonlatos a Wikipédiához: közösségi munka. A közösségben pedig vannak motiváltabb és kevésbé motivált, tehetségesebb és kevésbé tehetséges, több és kevesebb idővel rendelkező részt vevők. Ebből fakadóan a produktum minőségének színvonala is ingadozó, de ez nem a rendszert, hanem a használatot minősíti. Kellö átgondoltsággal kell használni az értékelésben. Ha megszervezzük köré a bekerülő adatok teljességét biztosító és hitelesítéséhez szükséges munkafolyamatokat, ha erőforrást rendelünk a folyamatos adattisztításhoz, ha gondoskodunk arról, hogy csak a validált adatokon alapuljanak a minősítésekhez használt statisztikák, akkor meglátjuk, hogy kiváló eszköz van a kezünkben, amit nagyon sok módon és területen lehet hasznosítani.

\section{Felhasznált irodalom}

Holl A. (2021). A Magyar Tudományos Művek Tára - alapvető információk és működési alapelvek. Magyar Tudomány, 182(1), 81-89. https://doi.org/10.1556/2065.182.2021.1.12

Sasvári P. (2020). Az MTA IX. Gazdaság- és Jogtudományok Osztály hazai folyóiratainak hivatkozás-alapú helyezése 2021-ben. ResearchGate https://doi.org/10.13140/RG.2.2.22119.06564

\section{A cikkben található online hivatkozások}

URL1: A IX. Osztály bizottságainak folyóiratlistája. https://mta.hu/data/dokumentumok/doktori_tanacs/IX.\%20Osztaly/2019/IX.O_folyoiratlistak_2017-OKT_AJB_PTB_GMB_2018.xlsx

URL2: Declaration on Research Assessment (DORA). https://sfdora.org/

URL3: 2015. évi CXXXI. törvény egyes, a felsőoktatás szabályozására vonatkozó törvények módositásáról. http://njt.hu/cgi_bin/njt_doc.cgi?docid=176694.96152

\section{A cikk APA szabály szerinti hivatkozása}

Bilicsi E. (2021). Hazai folyóiratok minősítése a Magyar Tudományos Művek Tára alapján. Belügyi Szemle, 69 (5), 723-733. https://doi.org/10.38146/BSZ.2021.5.1 